https://doi.org/10.3126/pragya.v8i01.42426

\title{
Time Travel in Kurt Vonnegut's Slaughterhouse-Five
}

\section{Ravi Kumar Shrestha*}

\begin{abstract}
This paper deals with Kurt Vonnegut's experimentation with his notion of time travel in his experimental and postmodern science fiction Slaughterhouse-Five. This paper deals with some statements of problem such as why does the novelist use the idea of time travel? Why does he deconstruct traditional concept of time, traditional plot and history? To show Billy pilgrim's time travel, the protagonist and war prisoner of Slaughterhouse at Dresden, the linear plot and mechanical/ traditional concept of time is not suitable, so the non-linear plot and the subjective/relative concept of time has been used. Qualitative research methodology has been used. Hence, the theories of Deconstruction, New Historicism and postmodern concept of time have been used. In this context, theorists such as Hengry Bergson, Albert Einstein, Jean-Francois Lyotard and so on and critics/writers such as Lois Tyson, Jago Morrison, Julie Armstrong, Todd F. Davis, OnurIsik, Daisaku Ikeda and so on have been used.
\end{abstract}

Key Words: Time Travel, Experimental Fiction, Tralfamadore, New Historicism, Deconstruction, Dresden, Second World War, Slaughterhouse

\section{Introduction}

This paper explores how Kurt Vonnegut's Slaughterhouse-Five deals with the concept of time travel. I have used a qualitative research methodology to write this paper as I needed concepts such as time travel, time machine, deconstruction of time, traditional concept of plot, and history of the world war. As I did not need data about characters as human being in the novel, the research methodology is not the quantitative. Likewise, I have used the postmodern theories of time such as Einstein's concept of relativity and Bergson's concept of subjective time. Apparently this novel appears to be a war novel, but it is entirely an antiwar novel. The setting of this science fiction is Europe and America, but mainly Dresden, a German city, which was totally devastated by the Second World War. The concept of time travel makes the novel very fascinating. The non-linear plot and narrative technique of the novel make it entirely postmodern. The novel takes us back to different events at different times. The events interwoven in the novel takes us back and forth. Likewise, Vonnegut uses

\footnotetext{
* Mr. Shrestha is an Assistant Professor o f English, Patan Multiple Campus, TU, Nepal
} 
flashbacks in an interesting cinematic style. The novel appears to be fully postmodern and experimental regarding his use of time. In course of analyzing the concept of time travel, on the one hand, the paper defines time travel, the postmodern concept of time, and deconstruction of time. On the other hand, the paper shows how the novel is like the rewriting history of Second World War, gives the reasons for the use of time travel in this novel, uses non-linear narrative technique of the plot and uses different theoretical approaches that support the exploitation of time travel by Kurt Vonnegut. What I have found through the research is the earth has been made a dystopian place to live by human beings as war mongers. Hence, the novelist's concept of hypothetical planet Trafalmadore appears to be a utopian planet/place for human beings for settlement. So, the novel appears to be an anti-war novel with help of the novelist's use of time travel, time machine, deconstruction of time, plot and history.

\section{Semi-autobiographical Novel}

Kurt Vonnegut's novel Slaughterhouse-Five which was published in 1969 is a semiautobiographical novel which narrates the story of a former American soldier Billy Pilgrim who took part in the Second World War. Billy Pilgrim who has been portrayed as the protagonist in the novel, time travels throughout the novel, which is the essence of the story. With the help of the concept of time travel, Vonnegut depicts the destruction and hollowness of the Second World War which annihilated Dresden, a German city, which had been inhabited by only civilians. In Slaughterhouse-Five, the narrator writes, "Listen: Billy Pilgrim has come unstuck in time. Billy has gone to sleep a sensible widower and awakened on his wedding day. He has walked through a door in 1955 and come out another one in 1941. He has gone back through that door to find himself in 1963. He has seen his birth and deaths many times ...” (19). These lines indicate Billy's journey through time. The entire novel reflects Billy's time travel between his experience as a prisoner of war and family life in 1950s and 1960s on the earth and his time on the utopian planet Tralfamadore.

\section{Application of Time Theory and Time Travel}

According to Oxford Advanced Learner's Dictionary, time travel means totravel through time into the past or the future. This is a hypothetical, important and popular concept used in science fiction. This concept is seen as a way to challenge human destiny i.e. the time travel is used in fictions or movies to prevent a loved one's death or to change the course of history. The idea of travel has been exploited in different books, movies and TV shows with different reasons. As far as books are concerned, besides Slaughterhouse-Five, time travel has been used in different books such as Time's Arrow by Martin Amis, Time Machine by H.G. Wells, 11/22/63 by Stephen King, The Time Traveler's wife by Audrey Niffenegger, etc. However, Wells'Time Machine can be regarded as the pioneer science fiction which 
reflects the use of time travel and which paves a way for others to exploit the time travel as a powerful concept. Intisar Khaleel writes, "The Time Machine (1895) is a novel in which Wells uses time machine as a vehicle that allows an operator to travel through time to gain mechanical control over time as well as return to the present to bring back history to know the effects and the consequences of the present on the future (Ibid)" (90). Likewise, according to ancient Hindu Mythology, the Mahabharat which was written about 700 B.C. narrates the time travel story of the king Revaita who travels to another world to meet the creator Brahma. When the king returns to the earth, he is shocked to know that many ages have passed. Regarding time travel, time is not regarded as absolute, but it is regarded as relative and subjective as Einsteins' theory of relativity defines. According to Stephen Hawking, "In the theory of relativity there is no unique absolute time, but instead each individual has his own personal measure of time that depends on where he is and how he is moving” (21). Vonnegut seems to have exploited such a concept of time to show Billy's time travel in Slaughterhouse-Five.

The time travel refutes the chronometric and objective time, about which Jago Morrison writes Einstein's views towards time in Contemporary Fiction, "In his work on relativity, Einstein explicitly refutes the idea that chronometric time (the time of the clock) progresses evenly in all circumstances" (36). The concept of time travel that is used by Vonnegut in Slaughterhouse-Five is a postmodern and experimental one as Julie Armstrong argues, "Some postmodern work employs frequent time shifts; this is apparent in SlaughterhouseFive by Kurt Vonnegut” (103). Vonnegut's protagonist Billy Pilgrim was born in 1922 in Ilium, New Work and studied to be an optometrist before being drafted to the Second World War. While he was working with the infantry in Europe during the war, he was taken prisoner by the Germans and taken to an old slaughterhouse. Vonnegut uses time travel as his narrative technique to make his fiction postmodern and experimental. He shows his time travel, "Billy is spastic in time, has no control over where he is going next, and the trips aren't necessary fun. He is in a constant state of stage fright, he says, because he never knows what part of his life he is going to have to act in next" (19). In 'Reflections of Time in Postmodern Literature', Tatyana Fedosova argues giving postmodern concept of time:

The literary world represents a complex, multiplane construction with a narrative structure and a story line, where the objective characteristics of time are transformed. Time becomes unsteady, diverse and reversible. Text time (story time, the time of narration) is multidimenstional and discrete, retrospective and prospective, unsteady and unstable. Shifts in time cause shifts in space ... (81)

The above lines indicate how the grand narrative concept of time i.e. time as objective and absolute has been transformed. The Aristotalean concept or Newton's concept of 
chronometric or absolute time has been changed. Instead, time as subjective and relative is used in the postmodern era.

Vonnegut's narrative strategy of the story reveals why he creates a hypothetical planet. Then the story again starts in 1968 when Billy has a plane crash while he is flying to Montreal from Ilium to take part in the International Conference of optometrists. Everyone is killed but Billy, who is hospitalized. Though he is a lone survivor of a plane crash, he has a grave head injury and he starts time traveling. His recollections come after the plane crash. According to Billy, he was kidnapped by Tralfamadorians and taken to their planet Tralfamodore. Vonnegut writes, "He said, too, that he had been kidnapped by a flying saucer in 1967. The saucer was from the planet Tralfamadore, he said” (21). Tralfamadore has been created as an imaginary planet by Vonnegut which becomes like the utopian one for people of the earth like Billy who have traumatic experiences of the inhuman, cruel and destructive Second World War. Hence, Billy time travels to escape from the devastating consequences of the war and to live in isolation pleasantly. In this context, OnurIsik writes:

All along the novel, the narrative changes. From time to time, Kurt Vonnegut interrupts the narration and starts to give information on the details of the Second World War and his experiences. By creating such an impressive atmosphere Vonnegut aims to show a utopian-like world. Yet, from Pilgrim's point of view, having a planet means escape from the horrifying images of the war. (359)

Thus, creating the fictitious planet, Vonnegut wants to show that people on the earth are terrorized and dehumanized by the World War in such a way that any fictitious planet like Tralfamadore appears to be like a utopian one, while the earth appears to be the dystopian one. Vonnegut gives a pleasant and lively picture of Tralfamadorians/creatures on the Tralfamadore. He writes, "The creatures were friendly and they could see in four directions. They pitied Earthlings for being able to see only three. They had many wonderful things to teach Earthlings, especially about time” (21). It indicates that time is regarded as the fourth dimension through which Billy travels like Tralfamadorians.

\section{Use of Postmodern Narrative Technique}

Vonnegut uses a postmodern narrative technique which uses time travel as a vehicle to unveil the horrors of the Second World War. Postmodernism deconstructs the traditional notion of time which is also regarded as a classical or an Aristotalean concept of time. Such a postmodern concept of time seems to be very powerful technique for the SF writers such as Vonnegut to go beyond the established norms of fiction writing. Previously, the classical time which is regarded as fixed or absolute truthhas been challenged by postmodern concept of time which indicatesthat time is subjective and relative. In this context, Julia Armstrong quotes Lyotard, "Jean-Francois Lyotard rejects all proof or truth claims and attacks, the 
Grand Narratives or ideologies that control individual and society” (100). It reflects how a great postmodern thinker and theorist Lyotard regards postmodernism as the deconstruction of modernism, too. So, Vonnegut uses time as subjective which is also regarded as psychological as time is used in accordance with the psychological state of the narrator. Hence, according to the psychological state of the narrator/protagonist, the writer moves forward and backward in time, which is known as time travel. On the one hand, Billy had the traumatic effect of the war; on the other hand, he had the impact of war movies on his psyche, which becomes clear from "Billy saw the war movies backwards and forwards-and then it was time to out into his backyard to meet the flying saucer" (61). So, Billy's use of time is very subjective and psychological in treating with war experiences. In this context, David Mendeloff writes, "We know, in fact, that war leads to trauma for large numbers of people, including soldiers who fight and civilians who are caught in the crossfire or forced to flee fighting. Wartime brutality and atrocity, such as mass killing, ethnic cleansing, torture, and rape, can also be psychologically traumatic for both soldiers and civilians" (594). Thus, the postmodern concept of time Vonnegut uses in this novel is psychological.

One very important aspect of the postmodern narrative technique of Vonnegut is he focuses on the consciousness of the time traveler Billy. His time travel entirely depends upon his consciousness, feelings and perception. His level of consciousness reflects his brain damage, frustration, and depersonalization caused by the World War. Vonnegut's statement "Billy, knowing the plane was going to crash pretty soon, closed his eyes, traveled in time back to 1944" (128) reflects Billy's time travel to the past, which indicates how his consciousness works with psychological time. Daisaku Ikeda rightly writes about Hengry Bergson's theory of time:

According to Bergson's theory of time, the division into past, present, and future is the product of human consciousness . . Bergson considered the true nature of consciousness to be in flux, and he spoke of "flowing time." Time perceived from the physical, objectiveviewpoint is time past. In contrast, "flowing time" is the flow of consciousness or of life itself. In essence, there is no distinction between past, present, and future, since they are created by the flow of consciousness. What is inseparable becomes separated in our minds (73).

Thus, Ikeda shows that time is in flux and so is consciousness. So, time traveler travels to and fro.

Likewise, to make Billy's time travel effective and purposeful, Vonnegut uses the non-linear narrative technique, which is one of the features of postmodernism, in Slaughterhouse-Five. The plot of Slaughterhouse-Five is non-linear as it has no fixed beginning, middle part and ending, which means that the plot has no chronological order of events. The events in the novel are randomly interwoven in accordance with the time traveler's travel. Jing Shi's 
argument "Non-linear narrative does not follow chronological order of events, and behaves itself in an abnormal way, such as chaotic space-time view or transformation of personal perspectives" (554) is very relevant here. One powerful example of the non-linear plot Vonnegut constructs is "The most important thing I learned on Tralfamadore was that when a person dies he only appears to die. He is still very much alive in the past ... All moments, past, present and future, always have existed, always will exist” (22). Using such a plot firstly, Vonnegut seems to give a mental solace to the war victims and secondly, he seems to show the meaninglessness and absurdity of the World War. Even Kyohei Yoshizu comments, "One of the artist's purposes- especially when he is haunted by traumatic memories like Vonnegut- is to "arrest" time and deny the inevitability of death. The distorted narration of events in Slaughterhouse-Five thus reflects Vonnegut's view of time . ..” (86). When such a non-linear plot is used, the events become spatialized and the time is spatialized, too. Sharon Spencer writes:

... the spatialization of time in the novel isthe process of splintering the events that, in atraditional novel, would appear in a narrative sequence and of rearranging them so thatpast, present, and future actions are presented in reversed, or combined, patterns; when thisis done, the events of the novel have been "spatialized" for the factor that constitutes their orientation to reality is the place where they occur. One of the most obvious effects to be achieved by means of this process is simultaneity: the presentation of two or moreactions in different places occurring at the same moment in time. In this way, a novelist... may dissolve the distinctions between past, present, and future as they are dissolved in dreams and in the stream-ofconsciousness flow. 156-57)

In course of narrating Billy's time travel, Vonnegut's narrative technique becomes like rewriting the history. In place of giving objective details of the Second World War as the traditional historians do, he makes his narrative very subjective expressing Billy's personal experiences with the war deconstructing the traditional notion of history. Isik's statements "The ironies and non-linear narrative of Vonnegut give a different place of the American Literature" and "Throughout the novel, Billy Pilgrim experiences a series of striking incidents in the course of the Second World War which makes Slaughterhouse- Five notable from the point of the New Historicism, too" (358) indicate that the novel is written from the perspective of New Historicism. In Critical Theory Today, Lois Tyson shows the difference between Traditional History and New Historicism, "Traditional historians ask, "What happened?" and "What does the event tell us about history?” In contrast, new historicists ask, "How has the event been interpreted?" and "What do the interpretations tell us about the interpreters?'”' (278). Isik again comments on the novel from the point of view of New Historicism: 
However, one of the most important air raids in the Second World War is Bombing of Dresden. Because of its horrifying nature, this air raid is still a debatable issue; so, nobody can mention the full certainty of the minor incidents. According to the New Historicist approach, the incidents took place in the past cannot be fully reachable. There is neither a universal truth, nor a sole data to be presented. Hence, each detail must be investigated mindfully. (358)

Thus, using New Historicist narrative technique, Vonnegut tries to say that there are no universal truths about the past such as universal truths about the Second World War. Whatever is known about it at present is through the interpretation of the narrator, which is subjective and psychological rather than objective.

With the help of the notion of time travel, Vonnegut shows the difference between this real planet earth that is inhabitated by human beings and the fictitious planet Tralfamadore that is inhabitated by Tralfamadorians/aliens. His protagonist Billy finds the earth devastated by the Second World War in such a way that there is a decay of humanity and spirituality, whereas Tralfamadore is such a planet where time, memory and life of living beings are taken entirely different. This notion of time is similar to Jorge Luis Borges' notion that Jago Morrison writes, "Borges invites the reader to imagine a place in which time, memory, history, and even language itself are structured in a radically different way" (30). Isik comments on Slaughterhouse-Five exactly like this:

It is seen that Slaughterhouse- Five's protagonist, Billy Pilgrim stands as an example of a lonely individual. Pilgrim's experiences on the front and his trauma after the Second World War show the devastating power of war. Even the survivors of the war carry the wounds of this experience psychologically. So, that does not have to be just a physical wound. It is clearly seen that Pilgrim's life and Tralfamadorians' way of living are antipodes and the contrast of them underlines the decay of humanity and humane values. (364)

Thus, Vonnegut's objective of using the time travel technique is to unveil the truth that the earth has been so much devoid of humanity and spirituality because of the war that human beings like Billy become desirous of escaping from it to settle in any other planet like the fictitious Tralfamadore, where living beings don't have to suffer from death as people do on the earth.

Although Vonnegut's novel revolves round the idea of time travel as Billy time travels throughout the novel, he wants to reveal the devastating impact of Second World War on Dresden and its consequences on people. Anyway, the novel is not the war novel, but it is written as an anti-war novel. Vonnegut promises O'Here's wife that he will not glamorize the war. Vonnegut says, “'I tell you what,'I said, 'I’ll call it "The Children’s Crusade.” (13). It is an indication of the anti-war novel. The novel neither glorifies the war nor 
valorizes the war heroes as Odyssey is done in Homer's epic Odyssey and great heroes are done in the Mahabharat and the Ramayana. Instead the fall of humanity, spiritual decay and the fall of European civilization are shown revealing the negativity of the war. Vonnegut does not seem to be the supporter of any political ideology and any powerful nation. Instead, he becomes in favour of humanity and humanistic values. In his book Kurt Vonnegut's Crusade, Todd F. Davis writes, "While Vonnegut lacks a rhetoric of moral certainty, he does notlack a moral rhetoric. This lack of certainty is result of Vonnegut's disillusionment with the utopian claims of nationalism and science, making it virtually impossible for him to argue for a specificideology or program of morality” (47).

\section{Deconstruction of Time and Plot}

The entire novel reflects the deconstruction of not only the plot but also of the mechanical or chronometrical time. Billy is not aware of the clock time. So, he does not belong to any particular age, but he keeps on time traveling shifting from one frame of time into another. In his utopian/fictitious planet Tralfamadore, Vonnegut writes, “And Billy zoomed back in the time of his infancy. He was a baby who had just been bathed by his mother... And then Billy was a middle-aged optometrist again, playing hacker's golf this time- on a blazing summer Sunday morning” (69). His loss of memory in this planet as “'Where am I?' said Billy Pilgrim” reflects absurdity and deconstruction of clock time. His time travel shows his circular concept of birth-life-death and again birth. After his death due to shooting by Paul Lazzaro's hired assassin in 1976, he again swings back to the life at the point in 1945, which indicates deconstruction of the classical clock time theory.

\section{Conclusion}

In this way, this paper shows that Vonnegut's Slaughterhouse-Five is an anti-war postmodern science fiction which reveals all the stages of Billy Pilgrim's life and his personal experiences of the most frightening Second World War. Focusing on the time travel which the protagonist Billy Pilgrim does, Vonnegut uses non-linear plot and subjective or psychological time deconstructing history and time. The fragmentation of time and plot reflects Billy's experiences with the destruction of Dresden by Second World War and the Tralfamadorean's perception of time theory. Thus, this paper defines time travel, applies Postmodern concept of time, does experimentation in time, plot and narrative strategy and finally expresses the writer's experiences as well. Anyway, his concept of time travel to Tralfamadore is to get rid of the traumatic experiences of the war. 


\section{Works Cited}

Armstrong, Julie. Experimental Fiction. London: Bloomsbury, 2014.

Davis, Todd F. Kurt Vonnegut's Crusade. New York: State University of New York Press, 2006.

Fedosova, Tatyana. "Reflections of Time in Postmodern Literature." Athens Journal of Philosophy, Vol. 2, Issue 2, pp. 77-88.

Hawking, Stephen. A Brief History of Time. File:/// WINDOWS/Desktop/blahh

Khaleel, Intisar. “Time Travel in Kurt Vonnegut's Slaughterhouse-Five.” ResearchGate, the Number-224, Vol. 1, 2018.

Ikeda, Daisaku.Life an Enigma, Precious Jewel. Tokyo: Kodansha International, 1942.

Isik, Onur. Creating a Planet: A New Historical Study on Slaughterhouse-Five. 2016, pp. 375- 365.

Mendeloff, David. “Trauma and Vengeance: Assessing the Psychological and Emotional Effects of Post-Conflict Justice.” Human Rights Quarterly, Vol. 31, No. 3, 2009, pp. 592- 623.

Jago, Morrison. Contemporary Fiction. London: Routledge, 2003.

Shi, Jing. “On the Postmodern Narrative Technique in Slaughterhouse-Five." Theory and Practice in Language Studies, Vol. 9, No. 5, May 2019, pp. 553- 561. ISSN 17992591.

Spencer, Sharon. Time and Structure in the Modern Novel. New York UP, 1971.

Lois Tyson. Critical Theory: A User-Friendly Guide. New York and London: Garland Publishing, Inc.,1999.

Vonnegut, Kurt. Slaughterhouse-Five. London: Vintage, 2000.

Yoshizu, Kyohei. "Stop the Clops: Vonnegut's Conception of Time in SlaughterhouseFive.” Social and Cultural Studies, No. 33, 2013, pp. 85-90. 